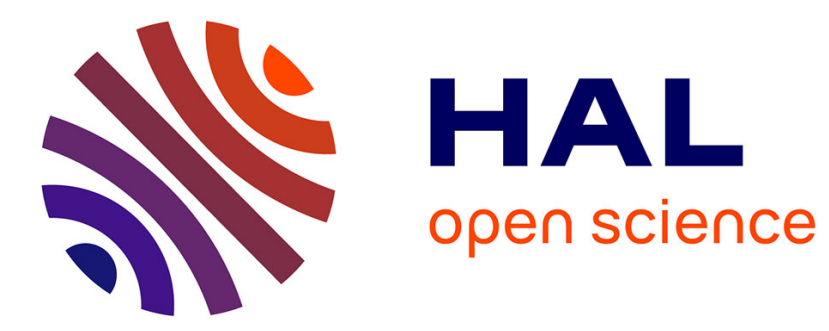

\title{
Study of the alkaline environment in mixed alkali compositions by multiple-quantum magic angle nuclear magnetic resonance (MQ-MAS NMR)
}

A. Angelopoulou, V. Montouillout, Dominique Massiot, G. Kordas

\section{- To cite this version:}

A. Angelopoulou, V. Montouillout, Dominique Massiot, G. Kordas. Study of the alkaline environment in mixed alkali compositions by multiple-quantum magic angle nuclear magnetic resonance (MQ-MAS NMR). Journal of Non-Crystalline Solids, 2007, 354 (2-9), pp.333 - 340. 10.1016/j.jnoncrysol.2007.08.091 . hal-03463607

\section{HAL Id: hal-03463607 \\ https://hal.science/hal-03463607}

Submitted on 2 Dec 2021

HAL is a multi-disciplinary open access archive for the deposit and dissemination of scientific research documents, whether they are published or not. The documents may come from teaching and research institutions in France or abroad, or from public or private research centers.
L'archive ouverte pluridisciplinaire HAL, est destinée au dépôt et à la diffusion de documents scientifiques de niveau recherche, publiés ou non, émanant des établissements d'enseignement et de recherche français ou étrangers, des laboratoires publics ou privés. 


\title{
Study of the alkaline environment in mixed alkali compositions by multiple-quantum magic angle nuclear magnetic resonance (MQ-MAS NMR)
}

\author{
A. Angelopoulou b, V. Montouillout ${ }^{\mathrm{c}}$, D. Massiot ${ }^{\mathrm{c}}$, G. Kordas ${ }^{\mathrm{a}, \mathrm{b}, *}$ \\ ${ }^{a}$ Sol-Gel Laboratory, Institute of Materials Science, NCSR 'DEMOKRITOS', 15310 Aghia Paraskevi Attikis, Greece \\ ${ }^{\mathrm{b}}$ Department of Materials Science, School of Natural Sciences, University of Patras, 26500 Patras, Greece \\ ${ }^{\mathrm{c}}$ Centre de Recherches sur les Matériaux à Haute Température, CNRS, $1 D$ Avenue de la Recherche Scientifique, 45071 Orléans cedex 2, France
}

Available online 19 November 2007

\begin{abstract}
45S5 Bioglasses of the composition $46.1 \mathrm{SiO}_{2}-2.6 \mathrm{P}_{2} \mathrm{O}_{5}-26.9 \mathrm{CaO}-(24.4-x) \mathrm{Na}_{2} \mathrm{O}-x \mathrm{Me}_{2} \mathrm{O}(\mathrm{Me}=\mathrm{Li}$ or $\mathrm{K})$ have been investigated using MAS NMR and MQ-MAS NMR methods. The analysis of the ${ }^{29} \mathrm{Si}$ MAS NMR spectrum revealed two lineshapes whose chemical shift is consistent with two silica $\mathrm{Q}_{n=2,3}$ species. The ${ }^{31} \mathrm{P}$ MAS NMR spectrum reveals the effect of both Na and Ca ions. The chemical shift of the observed ${ }^{31} \mathrm{P}$ signal is intermediate between those of $\mathrm{Na}_{3} \mathrm{PO}_{4}$ (near $\left.10 \mathrm{ppm}\right)$ and $\mathrm{Ca}_{3}\left(\mathrm{PO}_{4}\right)_{2}\left(\right.$ near $3-0$ ppm) species. The ${ }^{23} \mathrm{Na}$ MAS NMR spectra were observed in the alkali oxide composition: $24.4 \mathrm{Na}_{2} \mathrm{O}, 12.2 \mathrm{Na}_{2} \mathrm{O}-12.2 \mathrm{~K}_{2} \mathrm{O}$ and $12.2 \mathrm{Na}_{2} \mathrm{O}-12.2 \mathrm{Li}_{2} \mathrm{O}$. The substitution of $\mathrm{Na}$ with $\mathrm{Li}$ or $\mathrm{K}$ was done to determine the extend of alteration of the glass structure. This goal was best accomplished by ${ }^{23} \mathrm{Na}$ MQ-MAS NMR. The two-dimensional spectra revealed three sites in the $24.4 \mathrm{~mol} \% \mathrm{Na}_{2} \mathrm{O}$ glass. These sites were not resolved in the 1D MAS NMR spectroscopy. In the mixed glasses, only two sites were obtained.
\end{abstract}

(C) 2007 Elsevier B.V. All rights reserved.

PACS: 61.43.Fs; 61.18.Fs; 82.56.Ub; 82.56.Fk

Keywords: Bioglass; Mixed alkali effect; NMR, MAS NMR and NQR

\section{Introduction}

Bioglasses are mainly produced by glassy oxide mixtures with silicate and phosphosilicate composition [1]. The backbone of phosphosilicate glass structure is the silicaoxygen, $\mathrm{SiO}_{4}$, and the phosphorus-oxygen, $\mathrm{O}=\mathrm{PO}_{3}$, tetrahedral network. These $\mathrm{SiO}_{4}$ and $\mathrm{O}=\mathrm{PO}_{3}$ tetrahedra are connected through bridging oxygens to form a continuous 3D network. The $\mathrm{Q}_{n}$ notation expresses the concentration of bridging oxygens per tetrahedron, where $n$ value is equal to the number of bridging oxygens $[2,3]$.

\footnotetext{
* Corresponding author. Present address: Sol-Gel Laboratory, Institute of Materials Science, NCSR 'DEMOKRITOS', 15310 Aghia Paraskevi Attikis, Greece. Tel.: +30 2106503301; fax: +30 210654790 .

E-mail address: gkordas@ims.demokritos.gr (G. Kordas).
}

The understanding of the glassy structure is very important to define the properties of bioactive glasses as well as determine the mechanism of conversion into hydroxyapatite (HA). An expanding research has been made on glasses and glass ceramics of $45-55 \%$ silica concentration. Hench and his co-workers initiated the research by studying the glass composition $45 \% \mathrm{SiO}_{2}-24.5 \% \mathrm{Na}_{2} \mathrm{O}-24.5 \% \mathrm{CaO}-$ $6 \% \mathrm{P}_{2} \mathrm{O}_{5}$, known as 45S5 Bioglass ${ }^{\circledR}[4,5]$. These bioactive glasses are biocompatible and have been investigated for the strong interfacial bonding with bone [6-9]. Their bioactivity is attributed to the formation, on their surface, of a hydroxycarbonated apatite (HCA) layer quite similar to the mineral part of bone. The bone has an organic part mainly of type I collagen and an inorganic part of crystalline mineral salts and calcium, which is present in the form of hydroxyapatite. The matrix is initially laid down as 
unmineralized osteoid (manufactured by osteoblasts). Mineralisation involves osteoblasts secreting vesicles containing alkaline phosphatase and acts as the centre for calcium and phosphate deposition. The vesicles then rupture and act as a centre for crystals to grow on.

According to Hench [2,6-9], when the bioactive glass comes into contact with physiologic fluids, a three-step mechanism of HCA formation occurs on the surface of the implant. This mechanism involves ion exchange, dissolution and precipitation. Ion exchange occurs at the bioactive glass surface where the cations $\mathrm{Na}^{+}$and $\mathrm{Ca}^{2+}$ from the glass exchange with $\mathrm{H}^{+}$from the surrounding solution. Network dissolution occurs through the breakage of $\mathrm{Si}_{-}$ $\mathrm{O}-\mathrm{Si}$ bonds by the action of hydroxyl ions $\left(\mathrm{OH}^{-}\right)$. Silanol groups $(\mathrm{SiOH})$ formed on the glass surface undergo rearrangement resulting in a silica-rich gel layer. Precipitation of calcium-phosphate-rich layer $(\mathrm{CaP})$ occurs on the surface though reactions of calcium and phosphate ions from the glass together with those from body fluids.

The calcium-phosphate-rich layer $(\mathrm{CaP})$ on the surface of the glass is similar to the apatite phase present in bone [10]. Once apatite nuclei are formed, they will grow spontaneously, since under normal physiological conditions our body fluid is highly saturated with the components of hydroxyapatite. Additionally, the degree of saturation of body fluid and the kinetics of hydroxyapatite precipitation will be enhanced because of the dissolution of ions, such as $\mathrm{Ca}^{+}$and $\mathrm{PO}_{4}^{3-}$, from the glass. The dissolution of group I and II modifying cations (alkaline and alkaline earths, respectively) from the glass also assists hydroxyapatite precipitation since it raises the local $\mathrm{pH}$ and consequently reduces the solubility of hydroxyapatite $[11,12]$.

The glass structure is highly affected by the nature and the proportion of the alkali metal ions incorporated into the glass. Thus, the determination of alkali metal ion environments can contribute to the understanding of the relationship between structure and properties. There is plenty of literature evidence [18-20] on the effects of the alkali metal content on the physical and chemical properties of the glasses.

As we already know, properties related to the ionic motion, such as alkali migration and ionic diffusion, are highly affected by the presence of a second alkali metal in the glassy system. The influence happens in such way that exhibits large deviations from additivity. This phenomenon is known as 'mixed alkali effect' [14].

Recently, Ingram suggested an approach of this theory based on the interactions of unlike cations (mismatch effect) and the relaxation of these interactions because of the cations coupled motion [15]. These two opposite facts greatly affect the strength of cations in different mixed alkali systems. Hence, in glasses, such as $\mathrm{Na}-\mathrm{Cs}$, where mismatch effect prevails, conductivity displays deep minima in comparison to glasses with similar cationic site size, such as $\mathrm{Na}-\mathrm{K}$, where the opposite effect is being displayed.

In order to approach these concepts, a vacancy-like model can be used. In this model, the total number of vacant sites corresponds only to a small portion of the number of cations present in the glass system [15]. These sites are available only when stereo-chemical conditions allow it. In this way, the migration of a big cation is not allowed when the surrounding vacant sites exist because of the motion of a smaller cation $[14,16]$.

Our present work reports magic angle spinning (MAS) and multiple-quantum (MQ-MAS) NMR of the 45S5 bioglasses to probe the environment of sodium as it presents a significant element in the process of HCA formation $[17,18,22,23]$. Since the bones contain other alkaline (in the form of alkaline phosphatase), we substituted sodium with potassium or lithium in order to evaluate the effect of the replacement of another alkali metal ion on the local sodium sites.

\section{Experimental procedures}

\subsection{Sample preparation}

45S5 Bioglasses of the composition $46.1 \mathrm{SiO}_{2}-2.6 \mathrm{P}_{2} \mathrm{O}_{5^{-}}$ $26.9 \mathrm{CaO}-(24.4-x) \mathrm{Na}_{2} \mathrm{O}-x \mathrm{Me}_{2} \mathrm{O}(\mathrm{Me}=\mathrm{Li}$ or $\mathrm{K})$ were prepared by the traditional melting method. Table 1 gives the exact compositions. The starting materials were commercial powders of $\mathrm{CaCO}_{3}, \mathrm{Li}_{2} \mathrm{CO}_{3}, \mathrm{Na}_{2} \mathrm{CO}_{3}, \mathrm{~K}_{2} \mathrm{CO}_{3}$, $\left(\mathrm{NH}_{4}\right)_{2} \mathrm{HPO}_{4}$ and $\mathrm{SiO}_{2}$.

Butches of appropriate compositions were melted in platinum crucibles. The melting procedure was as follows:

1. raised to $1200{ }^{\circ} \mathrm{C}$ with $20^{\circ} \mathrm{C} / \mathrm{min}$,

2. staying at $1200^{\circ} \mathrm{C}$ for $1 \mathrm{~h}$,

3. raised to $1400^{\circ} \mathrm{C}$ with $20^{\circ} \mathrm{C} / \mathrm{min}$, and

4. melted at $1400^{\circ} \mathrm{C}$ for $2 \mathrm{~h}$.

Then the melts were poured into graphite molds. The glass samples were annealed at $600^{\circ} \mathrm{C}$ for $1 \mathrm{~h}$. The temperature was lowered to $100^{\circ} \mathrm{C}$ with a rate of $2^{\circ} \mathrm{C} / \mathrm{min}$.

\subsection{Solid state NMR spectroscopy}

The high-resolution NMR spectra have been obtained at different principal field $\left(4.7 \mathrm{~T}-200 \mathrm{MHz}\right.$ for ${ }^{29} \mathrm{Si}, 7.3 \mathrm{~T}-$ $300 \mathrm{MHz}$ for ${ }^{31} \mathrm{P}$, and $9.4 \mathrm{~T}-400 \mathrm{MHz}$ for ${ }^{23} \mathrm{Na}$ ) on Bruker AVANCE instruments equipped with high speed MAS probeheads. The ${ }^{29} \mathrm{Si}$ spectra have been obtained at a frequency of $39.76 \mathrm{MHz}$ and a spinning speed of $5 \mathrm{kHz}$. About 25000 scans were accumulated with a recycle delay of $6 \mathrm{~s}$. The ${ }^{31} \mathrm{P}$ quantitative spectra were acquired at a frequency of $121.5 \mathrm{MHz}$ and a spinning rate of $10 \mathrm{kHz}$, using a single pulse sequence. Thirty-two scans were added with a recycling delay of $120 \mathrm{~s}$.

The ${ }^{23} \mathrm{Na}$ one-dimensional spectra have been recorded with small pulse angle $(\pi / 18)$ to ensure quantitative excitation of the central transition and a recycling delay of $1 \mathrm{~s}$. For the 2D multiple-quantum MQ-MAS experiments, we used the z-filtered pulse sequence [19] and a synchronized acquisition of the indirect dimension [20]. The two first 
Table 1

Compositions of all the glasses studied ( $\mathrm{mol} \%$ )

\begin{tabular}{llllll}
\hline Sample composition $(\mathrm{mol} \%)$ & $\mathrm{SiO}_{2}$ & $\mathrm{P}_{2} \mathrm{O}_{5}$ & $\mathrm{CaO}$ & $\mathrm{Na}_{2} \mathrm{O}$ & $\mathrm{K}_{2} \mathrm{O}$ \\
\hline $45 \mathrm{~S} \mathrm{Na}$ & 46.1 & 2.6 & 26.9 & 24.4 & - \\
$45 \mathrm{~S} \mathrm{Na}-\mathrm{Li}$ & 46.1 & 2.6 & 26.9 & 12.2 & - \\
$45 \mathrm{~S} \mathrm{Na}-\mathrm{K}$ & 46.1 & 2.6 & 26.9 & 12.2 & 12.2 \\
$45 \mathrm{~S} \mathrm{Na}-\mathrm{K}$ & 46.1 & 2.6 & 26.9 & 14.4 & 10 \\
$45 \mathrm{~S} \mathrm{Na}-\mathrm{K}$ & 46.1 & 2.6 & 26.9 & 10 & - \\
\hline
\end{tabular}

pulses were optimized to 4.5 and $1.6 \mu$ s for a rf-field of $140 \mathrm{kHz}$ and the z-filter pulse was a $90^{\circ}$ selective pulse of $11.5 \mu$ s with a rf-field of $11 \mathrm{kHz}$.

Chemical shifts are referenced to TMS, an $85 \% \mathrm{H}_{3} \mathrm{PO}_{4}$ solution and $\mathrm{NaCl}(1 \mathrm{~N})$ aqueous solution for ${ }^{29} \mathrm{Si},{ }^{31} \mathrm{P}$ and ${ }^{23} \mathrm{Na}$, respectively.

\section{Results and discussion}

\section{1. ${ }^{29}$ Si and ${ }^{31} \mathrm{P}$ solid state NMR characterization}

To deeply describe the structure of our glasses, we probe the local environment of silicium, phosphorus and sodium nuclei. Fig. 1 shows the ${ }^{29} \mathrm{Si}$ MAS NMR of the $45 \mathrm{~S} \mathrm{Na}$ $\left(24.4 \mathrm{~mol} \% \mathrm{Na}_{2} \mathrm{O}\right.$ ) glass. The spectrum exhibits a broad asymmetric line. This line can be deconvoluted in two Gaussian lines centered at $-79.5 \mathrm{ppm}$ and at $-83.1 \mathrm{ppm}$.

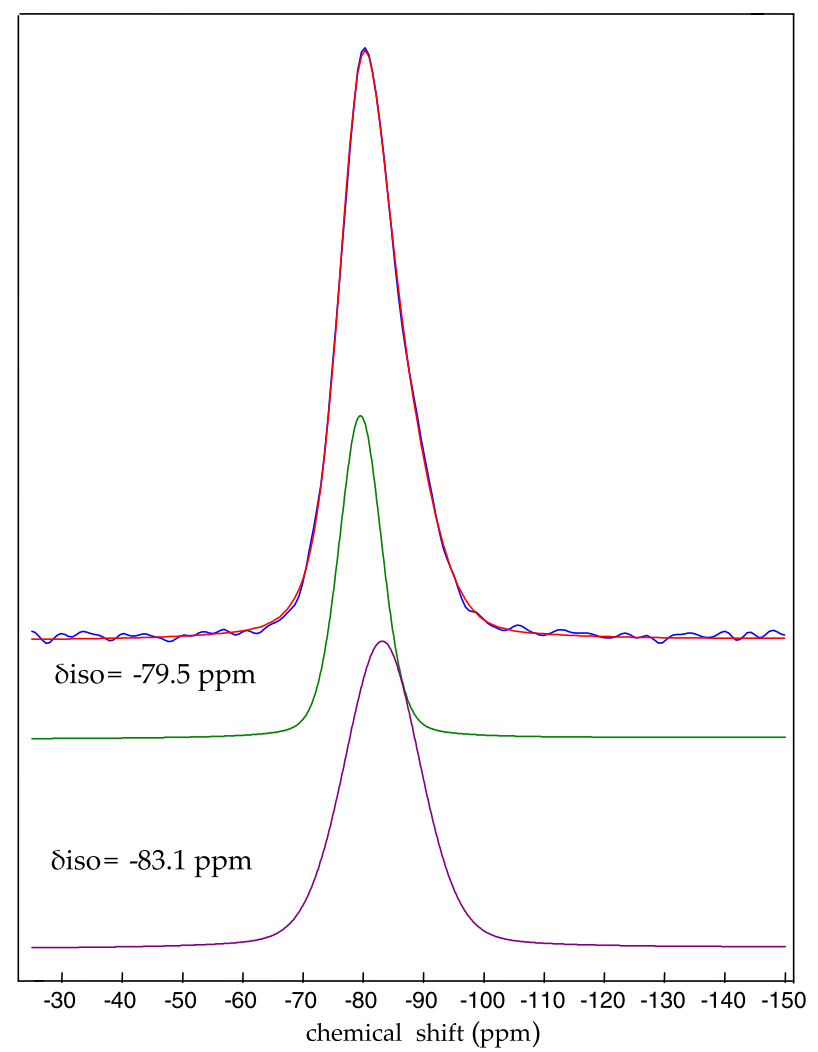

Fig. 1. ${ }^{29} \mathrm{Si}$ MAS NMR spectrum of the $46.1 \mathrm{~mol} \% \mathrm{SiO}_{2}-2.6 \mathrm{~mol} \% \mathrm{P}_{2} \mathrm{O}_{5^{-}}$ $26.9 \mathrm{~mol} \% \mathrm{CaO}-24.4 \mathrm{~mol} \% \mathrm{Na}_{2} \mathrm{O}$ glass.
As this composition contains a high concentration of alkali ions, it was expected that the phosphosilicate network would contain silicate tetrahedra with one or two NBO. Thus, the ${ }^{29} \mathrm{Si}$ peak at $-79.5 \mathrm{ppm}$ is assigned to $\mathrm{Si}\left(\mathrm{Q}_{2}\right)$ species and at $-83.1 \mathrm{ppm}$ to $\mathrm{Si}\left(\mathrm{Q}_{3}\right)$ species. Literature reports chemical shifts for $\operatorname{Si}\left(\mathrm{Q}_{2}\right)$ silicon species at the value of $-75 \mathrm{ppm}$ and for $\mathrm{Si}\left(\mathrm{Q}_{3}\right)$ at the value of $-88 \mathrm{ppm}$ for sodium silicate glasses [28]. The deviations from these values are attributed to the presence of (i) $\mathrm{Na}^{+}$and $\mathrm{Ca}^{2+}$ ions that are likely correlated with the phosphorus species in the glass and (ii) $\mathrm{Ca}^{2+}$ ions that preferentially correlate with $\mathrm{Si}\left(\mathrm{Q}_{2}\right)$ species [28]. Under these conditions, we explain the decrease in the chemical shifts of $\operatorname{Si}\left(\mathrm{Q}_{2}\right)$ species and the increase in the chemical shifts of $\operatorname{Si}\left(\mathrm{Q}_{3}\right)$ species. Fig. 1 indicates this change in silicon chemical shifts.

According to the literature [26,27], alkali ions preferably associate with $\mathrm{PO}_{4}$ tetrahedra, because the acidity of $\mathrm{SiO}_{2}$ and $\mathrm{P}_{2} \mathrm{O}_{5}$ oxides increases in the order $\mathrm{SiO}_{2}<\mathrm{P}_{2} \mathrm{O}_{5}$. The phosphorus environment should then be the most influenced by alkali-substitution. However, as can be seen in the Fig. 2, the ${ }^{31} \mathrm{P}$ MAS NMR spectra of $\mathrm{Na}, \mathrm{Li}, \mathrm{K}$ glasses together with two mixed alkali glasses are similar. In all the cases, the spectra exhibits a broad, quite symmetric line centered at $8 \mathrm{ppm}$. Only in the case of potassium glass composition $\left(46.1 \mathrm{SiO}_{2}-2.6 \mathrm{P}_{2} \mathrm{O}_{5}-26.9 \mathrm{CaO}-24.4 \mathrm{~K}_{2} \mathrm{O}\right)$, a second resonance can be observed at $3 \mathrm{ppm}$. The chemical shift of the main line is typical of phosphorus in an orthophosphate environment. The broadening can probably be attributed to a distribution of chemical shift due to the weak variations of local environment of phosphorus nuclei. This lineshape is currently observed in disordered materials. The recorded shift of $8 \mathrm{ppm}$ appears to be in the range of the shifts of $\mathrm{Na}_{3} \mathrm{PO}_{4}$ (at $10 \mathrm{ppm}$ ) and $\mathrm{Ca}_{3}\left(\mathrm{PO}_{4}\right)_{2}$ (at the region of 3-0 ppm) species [28]. For $\mathrm{Na}_{3} \mathrm{PO}_{4}$ the indicative phosphate species are the $\mathrm{P}\left(\mathrm{Q}_{1}\right)$ units in which three $\mathrm{BO}$ correlate with three $\mathrm{Na}[24,25]$. Consequently in $45 \mathrm{~S} \mathrm{Na}$ glasses where the chemical shift is observed because of the presence of $\mathrm{Na}$ and $\mathrm{Ca}$, the lineshape at $8 \mathrm{ppm}$ is assigned to $\mathrm{P}\left(\mathrm{Q}_{1}\right)$ species in which one of the $\mathrm{Na}$ is connected with a second $P\left(Q_{1}\right)$ specie in which one or two of the free $\mathrm{Na}$ may have been substituted by $\mathrm{Ca}$. This structure is denoted either by the $P\left[Q_{1}(3 \mathrm{Na})\right]-P\left[Q_{1}(2 \mathrm{Na})(1 \mathrm{Ca})\right]$, $\mathrm{P}\left[\mathrm{Q}_{1}(3 \mathrm{Na})\right]-\mathrm{P}\left[\mathrm{Q}_{1}(1 \mathrm{Na})(2 \mathrm{Ca})\right]$ or $\mathrm{P}\left[\mathrm{Q}_{1}(3 \mathrm{Na})\right]-\mathrm{P}\left[\mathrm{Q}_{1}(3 \mathrm{Ca})\right]$. The last of the three structures is less likely to be observed due to the difference in electronegativities of $\mathrm{Na}^{+}$and $\mathrm{Ca}^{2+}, 0.9$ and 1.0, respectively. Even if their difference is very low the substitution of $\mathrm{Na}^{+}$by $\mathrm{Ca}^{2+}$ would result in 


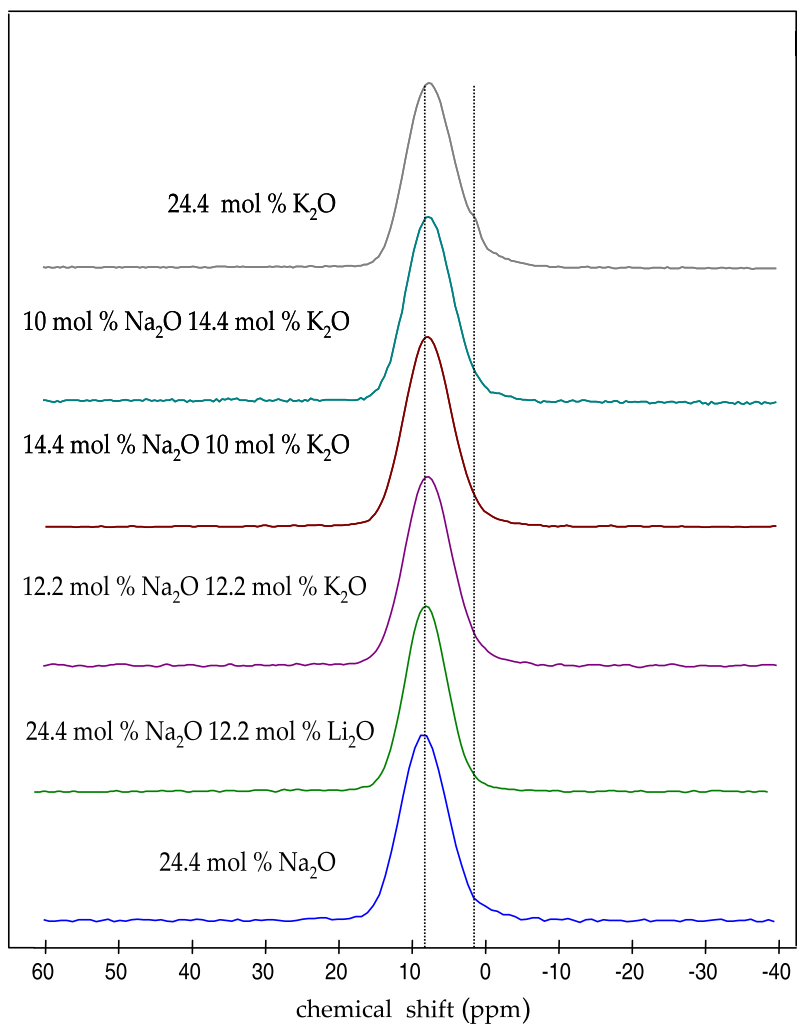

Fig. 2. ${ }^{31} \mathrm{P}$ MAS NMR spectra of Na glasses, $\mathrm{K}$ glasses and a mixed alkali series.

a more negative chemical shift because of the dislocation of charge from the oxygen and thus from the $\mathrm{P}-\mathrm{O}$ bond [28]. Unfortunately, this cannot be observed on the spectra, due to the broadening of the line consecutive to various local environments.

For the $45 \mathrm{~S} \mathrm{Na}-\mathrm{K}$ glass compositions, the ${ }^{31} \mathrm{P}$ MAS NMR spectra apart from the lineshape at $8 \mathrm{ppm}$ revealed a second one, with a weaker signal, at the region of 3$0 \mathrm{ppm}$. The cationic strength of alkali ions increases in the order of $\mathrm{Li}^{+}>\mathrm{Na}^{+}>\mathrm{K}^{+}[21]$, thus the presence of cations with lower strength results in the interaction of a smaller ratio of NBOs or a higher ratio of BOs and consequently - in the decrease of chemical shift [29]. Therefore, the chemical shift of the second lineshape drops off from $3 \mathrm{ppm}$ to $0 \mathrm{ppm}$ as $\mathrm{Na}$ concentration is decreased from $24.4 \mathrm{~mol} \% \mathrm{Na}_{2} \mathrm{O}$ to $0 \mathrm{~mol} \% \mathrm{Na}_{2} \mathrm{O}$ (or $24.4 \mathrm{~mol} \%$ $\mathrm{K}_{2} \mathrm{O}$ ). However, even in the potassium glasses the lineshape has a rather weak signal.

\section{2. ${ }^{23} \mathrm{Na} 1 \mathrm{D}$ and $2 \mathrm{D} M Q-M A S N M R$ characterization}

Fig. 3 shows the ${ }^{23} \mathrm{Na}$ MAS NMR spectra of the 24.4 $\mathrm{Na}_{2} \mathrm{O}, 12.2 \mathrm{Na}_{2} \mathrm{O}-12.2 \quad \mathrm{~K}_{2} \mathrm{O}$ and $12.2 \mathrm{Na}_{2} \mathrm{O}-12.2 \mathrm{Li}_{2} \mathrm{O}$ mixed alkali metal compositions. The spectra consist of a single broad asymmetric line with a steep low-field edge and a trailing high-field edge. This lineshape has previously been interpreted as linked to a distribution of electric field gradient (EFG) at the sodium site, and is typical of disor-

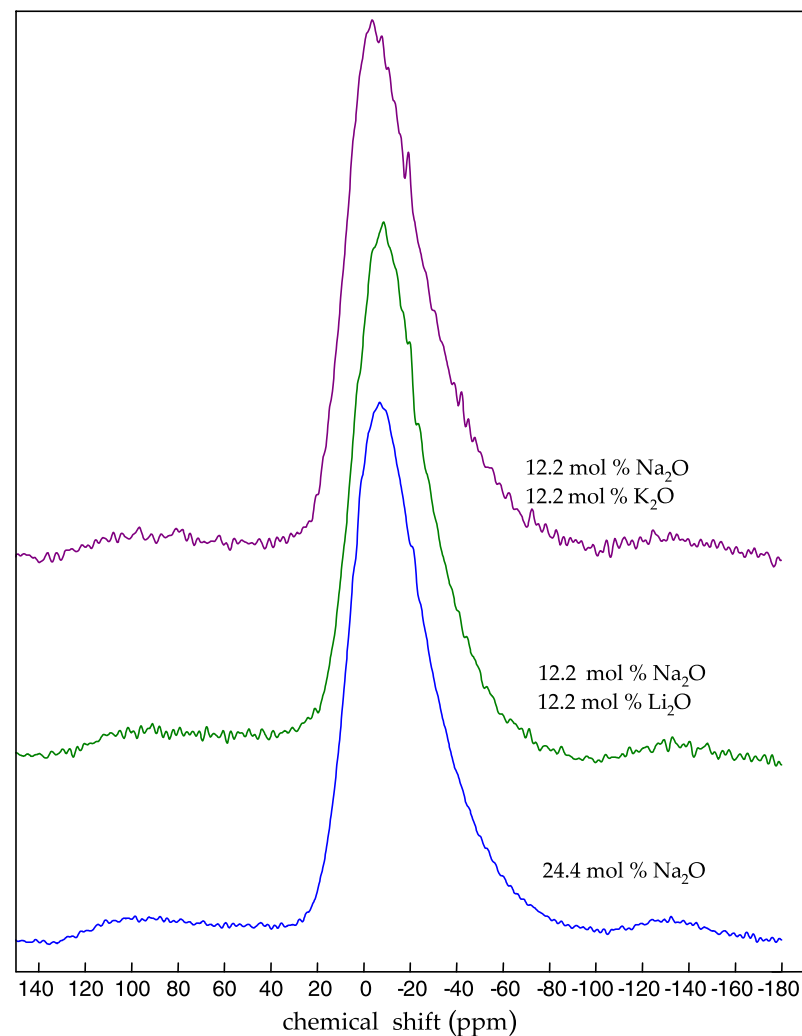

Fig. 3. ${ }^{23} \mathrm{Na}$ MAS NMR spectra of the $24.4 \mathrm{Na}_{2} \mathrm{O}, 12.2 \mathrm{Na}_{2} \mathrm{O}-12.2 \mathrm{~K}_{2} \mathrm{O}$ and $12.2 \mathrm{Na}_{2} \mathrm{O}-12.2 \mathrm{Li}_{2} \mathrm{O}$ mixed alkali glasses.

dered materials. The position of the maximum of the peak has been estimated at $4.4 \mathrm{ppm}, 6.8 \mathrm{ppm}$ and $8.8 \mathrm{ppm}$ for 12.2 $\mathrm{Na}_{2} \mathrm{O}-12.2 \mathrm{Li}_{2} \mathrm{O}$ glass, $24.4 \mathrm{Na}_{2} \mathrm{O}$ glass, and 12.2 $\mathrm{Na}_{2} \mathrm{O}-12.2 \mathrm{~K}_{2} \mathrm{O}$ glass, respectively.

This main line can be better described with the ${ }^{23} \mathrm{Na}$ MQ-MAS NMR experiments. The spectra obtained for $24.4 \mathrm{Na}_{2} \mathrm{O}, 12.2 \mathrm{Na}_{2} \mathrm{O}-12.2 \quad \mathrm{~K}_{2} \mathrm{O}$ and $12.2 \mathrm{Na}_{2} \mathrm{O}-12.2$ $\mathrm{Li}_{2} \mathrm{O}$ mixed alkali metal compositions are shown in Fig. 4. The ${ }^{23} \mathrm{Na}$ MQ-MAS NMR spectrum (Fig. 4) for the $12.2 \mathrm{Na}-\mathrm{K}$ glass - in comparison with the one for the 24.4 Na glass - illustrates an increase in $\mathrm{Na}$ 's chemical shift (of around $4 \mathrm{ppm}$ and not around $2 \mathrm{ppm}$ as it was estimated in the 1D characterization) which reveals a higher negative charge concentration in Na environment. According to the literature $[10,13,20]$, cations with smaller size (or higher charge) have a rather small coordination shell which contains a higher ratio of NBOs. Moreover, NBOs enclose the utmost negative charge concentration. The cation site size order and the order of cation strength is $\mathrm{K}^{+}>$ $\mathrm{Na}^{+}>\mathrm{Li}^{+}$and $\mathrm{Li}^{+}>\mathrm{Na}^{+}>\mathrm{K}^{+}$, respectively. Thus, in case of $\mathrm{Na}$ substitution by $\mathrm{K}$, because of its smaller size and higher strength, $\mathrm{Na}$ will interact with a higher ratio of NBO providing a higher negative charge concentration. On the other hand, in case of $12.2 \mathrm{Na}-\mathrm{Li}$ glass concentration because of Li smaller size and higher charge, Na substitution by $\mathrm{Li}$ results in smaller negative charge concentration in $\mathrm{Na}$ environment and consequently in a decrease in $\mathrm{Na}$ chemical shift (of around $4 \mathrm{ppm}$ and not 

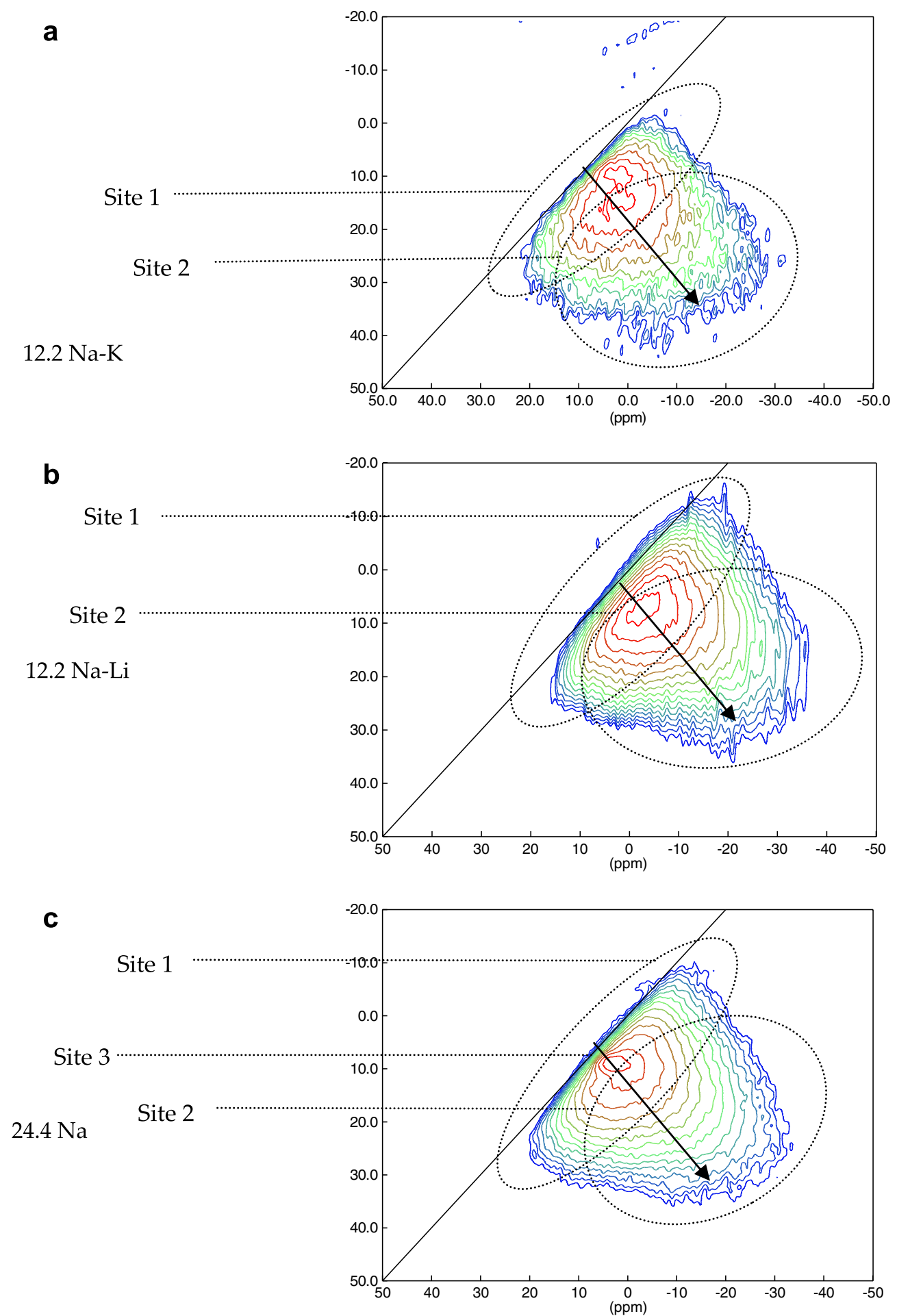

Fig. 4. ${ }^{23} \mathrm{Na}$ MQ-MAS NMR spectra for the $24.4 \mathrm{Na}_{2} \mathrm{O}, 12.2 \mathrm{Na}_{2} \mathrm{O}-12.2 \mathrm{~K}_{2} \mathrm{O}$ and $12.2 \mathrm{Na}_{2} \mathrm{O}-12.2 \mathrm{Li}_{2} \mathrm{O}$ mixed alkali species, where the horizontal and perpendicular axes represent the MAS dimension (in ppm) and the isotropic dimension (in ppm) of the sample, respectively and the inset line and the arrow correspond to the chemical shift (CS) and the QIS lines, respectively.

around $2.4 \mathrm{ppm}$ as it was estimated in the $1 \mathrm{D}$ characterization).

From these two-dimensional MQ-MAS spectra, it is possible not only to discuss the distribution of chemical shifts that are not accessible from a simple MAS spectrum but also to better describe the distribution of quadrupolar interaction. Indeed the spreading of the contour shape along the full line (CS line) is due to the chemical shift distribution, whereas, the spreading along the dotted line (QIS line) is due to a distribution of quadrupolar coupling constant. According to the observed lineshape, the signal should be attributed to at least two components for 12.2 
$\mathrm{Na}_{2} \mathrm{O}-12.2 \quad \mathrm{~K}_{2} \mathrm{O}$ and $12.2 \mathrm{Na}_{2} \mathrm{O}-12.2 \mathrm{Li}_{2} \mathrm{O}$ samples and three components for $45 \mathrm{~S} \mathrm{Na}$ glass. The ellipses over the spectra results from computer simulation indicating the $\mathrm{Na}$-sites present in the glasses. The complete simulation obtained for the spectra of $45 \mathrm{~S} \mathrm{Na}\left(24.4 \mathrm{~mol}_{0} \mathrm{Na}_{2} \mathrm{O}\right)$ glass is shown in Fig. 5. The simulated spectrum is composite resulting from the three components (Bottom theoretical spectra) deduced from the fitting procedure. The narrower signal (site 3 ), with a weak quadrupolar coupling constant $\left(C_{\mathrm{Q}}=1.2 \mathrm{MHz}\right)$ and no chemical shift distribution

\section{$24.4 \mathrm{Na}$}
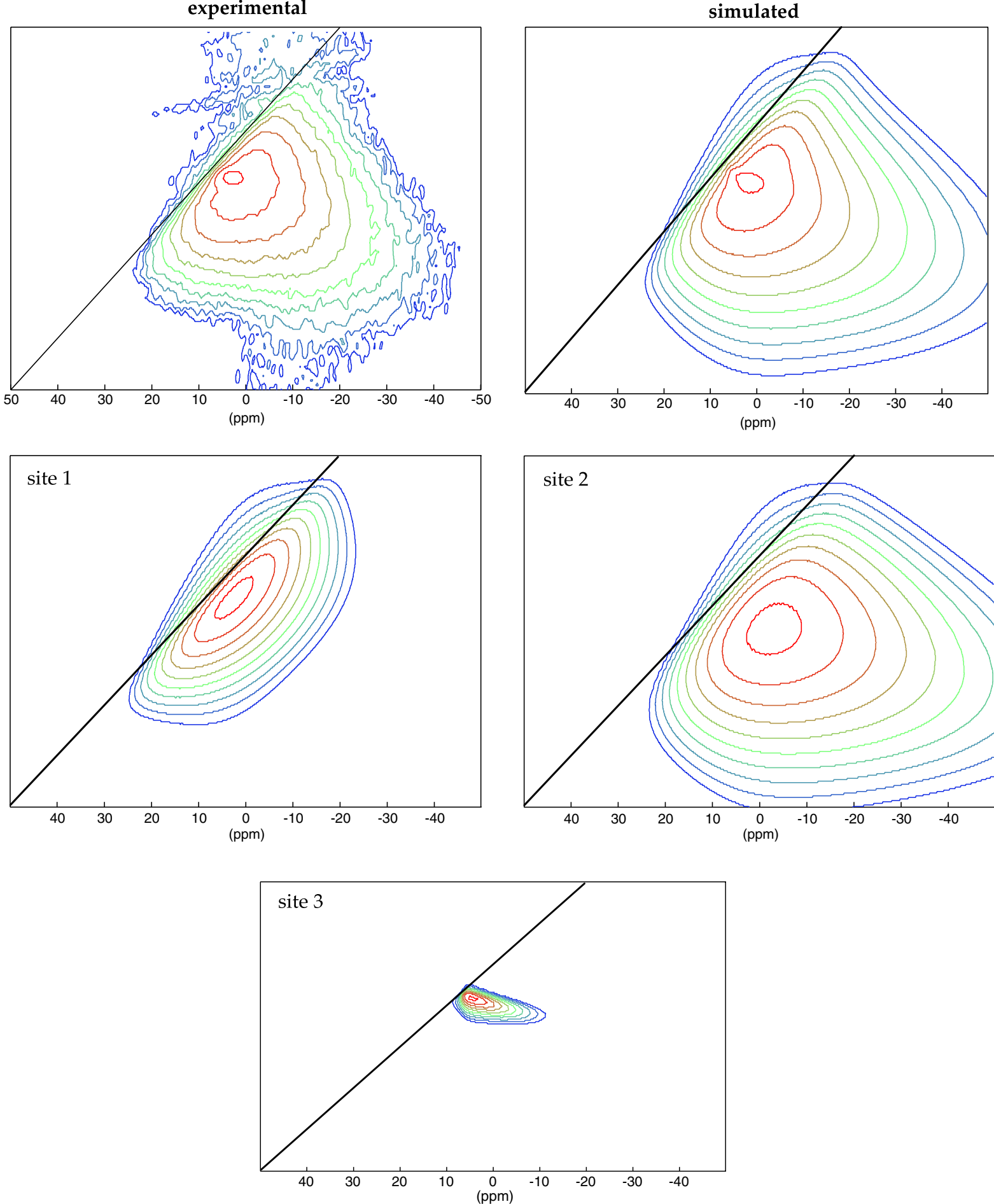

Fig. 5. ${ }^{23} \mathrm{Na}$ MQ-MAS NMR simulated and experimental spectrum of the $24.4 \mathrm{~mol} \% \mathrm{Na}_{2} \mathrm{O}$ oxide composition the horizontal and perpendicular axes as well as the inset line are the same as in Fig. 4 . Site $1\left(\delta_{\text {iso }}=6.0 \mathrm{ppm}, C_{\mathrm{Q}}=1.4 \mathrm{MHz}, \Delta \mathrm{CS}=20 \mathrm{ppm}\right)$, site $2\left(\delta_{\text {iso }}=6.8 \mathrm{ppm}, C_{\mathrm{Q}}=2.6 \mathrm{MHz}\right.$, $\Delta \mathrm{CS}=20 \mathrm{ppm})$, site $3\left(\delta_{\text {iso }}=6.6 \mathrm{ppm}, C_{\mathrm{Q}}=1.2 \mathrm{MHz}, \Delta \mathrm{CS}=1 \mathrm{ppm}\right)$. 


\subsection{Na-Li}
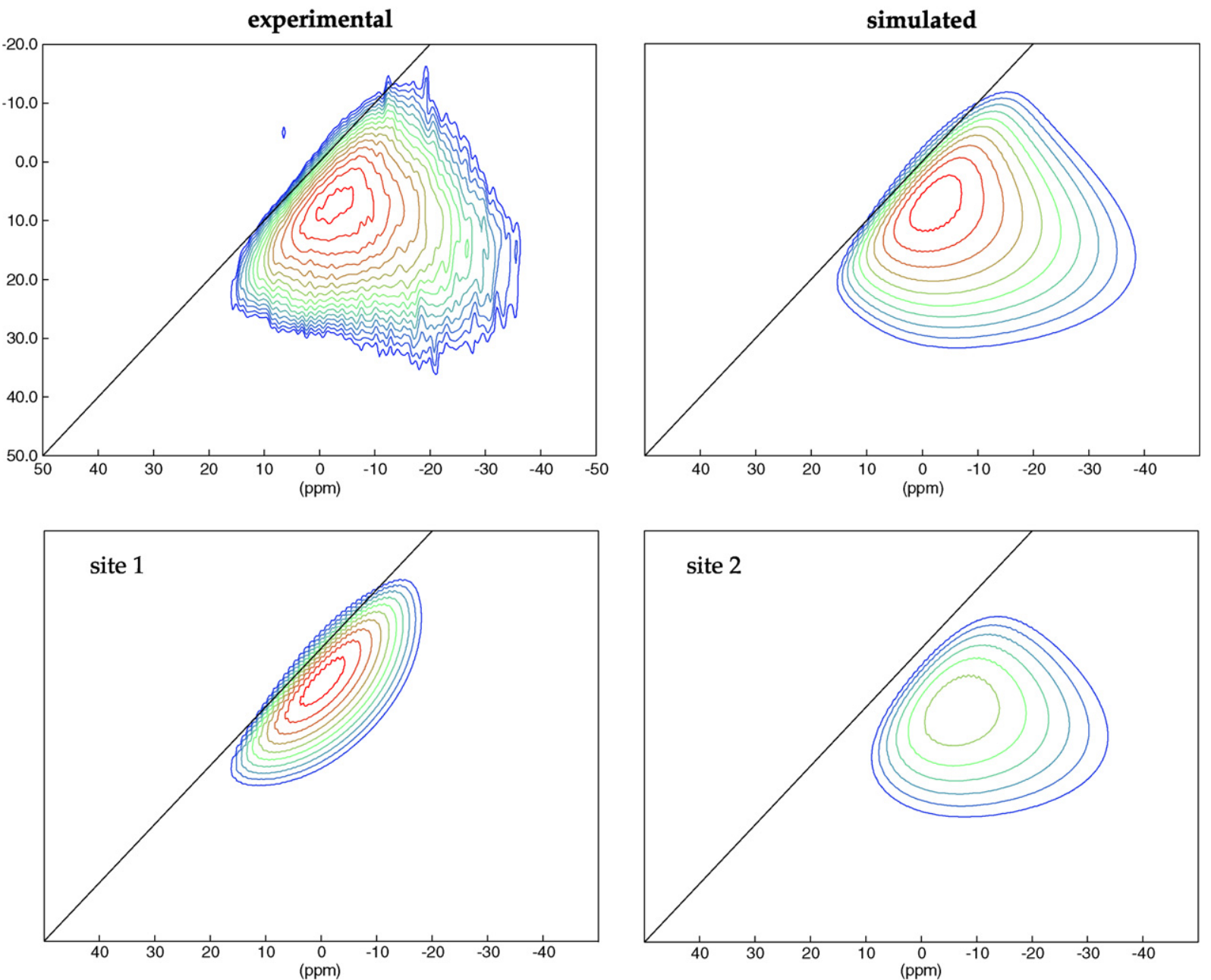

Fig. 6. ${ }^{23} \mathrm{Na}$ MQ-MAS NMR simulated and experimental spectrum of the $12.2 \mathrm{~mol} \% \mathrm{Na}_{2} \mathrm{O}-12.2 \mathrm{~mol} \% \mathrm{Li}_{2} \mathrm{O}$ alkali oxide composition the horizontal and perpendicular axes as well as the inset line are the same as in Fig. $4\left(\delta_{\text {iso }}=3.3 \mathrm{ppm}, C_{\mathrm{Q}}=1.4 \mathrm{MHz}, \Delta \mathrm{CS}=20 \mathrm{ppm}\right)$, site $2\left(\delta_{\text {iso }}=2.8 \mathrm{ppm}, C_{\mathrm{Q}}=2.6 \mathrm{MHz}\right.$, $\Delta \mathrm{CS}=20 \mathrm{ppm})$.

$(\Delta \mathrm{CS}=1 \mathrm{ppm})$ is probably due to a most ionic species. The addition of a second alkali leads to the absence of this species in $12.2 \mathrm{Na}-\mathrm{K}$ and $12.2 \mathrm{Na}-\mathrm{Li}$ glasses probably due to the mixed alkali effect. The simulated spectrum of $12.2 \mathrm{Na}-$ $\mathrm{Li}$ glass is shown in Fig. 6 and is composite resulting from the two components. At this point, we need to emphasize that consideration of one site cannot lead to satisfactory reproduction of the experimental spectra. Appropriate superposition of three and two sites in the sodium and mixed alkali glasses can reproduce the experimental spectra, respectively. We do not know which site is associated with the silica or phosphorus network and why the site 3 diminishes in the mixed alkali glasses.

According to the literature $[21,30]$, because of the order of cation strength, the ratio of electric charge distributed to the ionic radius of $\mathrm{Na}$ is higher than the electric charge in $\mathrm{K}$ 's ionic radius hence the ionic site is the energetically favorable for $\mathrm{Na}$. In a mixed alkali glass, $\mathrm{Na}$ will occupy the most ionic site while $\mathrm{K}$ the less ionic one therefore in
12.2 $\mathrm{Na}-\mathrm{K}$ glass the most ionic site 1 is distributed to $\mathrm{Na}^{+}$while site 2 to $\mathrm{K}^{+}$. As far as $12.2 \mathrm{Na}-\mathrm{Li}$ glass is concerned, ionic is the energetically favorable site for $\mathrm{Li}$ so site 1 is distributed to $\mathrm{Li}^{+}$while site 2 to $\mathrm{Na}^{+}$.

\section{Conclusion}

Nuclear magnetic resonance (NMR) spectroscopy is an attractive method for obtaining an insight into the structure of the glasses. From the present study using magic angle spinning (MAS) and multiple-quantum (MQ-MAS) NMR the following conclusions are proposed for the characterization of the $45 \mathrm{~S} 5$ bioglasses, and especially the description of sodium environments.

The ${ }^{29} \mathrm{Si}$ and ${ }^{31} \mathrm{P}$ solid state NMR characterization confirmed that the phosphosilicate network is mainly composed of silicate tetrahedra with one and two NBO $\left(\mathrm{Si}\left(\mathrm{Q}_{2}\right)\right.$ and $\mathrm{Si}\left(\mathrm{Q}_{3}\right)$ species) containing pyrophosphates units $\left(\mathrm{P}\left(\mathrm{Q}_{1}\right)\right.$ species $)$. The ${ }^{31} \mathrm{P}$ environment is not highly 
influenced by alkali-substitution as for the $\mathrm{Na}, \mathrm{Li}, \mathrm{K}$ and the mixed alkali glasses exhibit a main line at $8 \mathrm{ppm}$ and a second at $3 \mathrm{ppm}$ with a rather weak signal.

The ${ }^{23} \mathrm{Na}$ 1D and 2D MQ-MAS NMR characterization apart from the opposite variation of the chemical shift with the addition of two different alkalis revealed that one of the three Na-ionic sites is absent from the mixed alkali glasses as well. The absence of the ionic site illustrates the migration of $\mathrm{Na}^{+}$from this site to more energetically favorable ones. This motion of $\mathrm{Na}^{+}$lives behind vacant sites available only to $\mathrm{Li}^{+}$, because of their smaller size. In case of $\mathrm{K}^{+}$, either this ionic site is totally absent or the surrounding environment has changed in order the vacant sites to be available to $\mathrm{K}^{+}$.

\section{References}

[1] L. Stoch, M. Strodna, J. Mol. Struct. 77 (1999) 511.

[2] Butler, Harrods, Inorganic Chemistry: Principles and Applications, The Benjamin/Cummings Publishing Company, Inc., 1989.

[3] H. Grussaute, L. Montagne, G. Palavit, J.L. Bernard, J. Non-Cryst. Solids $263 \& 264$ (2000) 312.

[4] L.L. Hench, R.J. Splinter, W.C. Allen, T.K. Greenlee, J. Biomed. Mat. Res. 2 (1971) 117.

[5] L.L. Hench, A.E. Clark, J.R. Schaake, H.F. Schaake, Int. J. NonCryst. Solids. 8-10 (1972) 837.

[6] L.L. Hench, J. Am. Ceram. Soc. 74 (1991) 1487.

[7] L.L. Hench, K. West, Life Chem. Rep. 13 (1996) 187.

[8] L.L. Hench, J. Am. Ceram. Soc. 81 (1991) 1705.

[9] V.J. Shirtliff, L.L. Hench, J. Mat. Sci. 38 (2003) 4697.

[10] Q.Q. Hoang, F. Sicheri, A.J. Howard, D.S.C. Yang, Nature 425 (2003) 977.

[11] K.H. Karlsson, Ann. Chir. Gynaecol. 88 (1999) 226.
[12] S. Hayakawa, K. Tsuru, C. Ohtsuki, A. Osaka, J. Am. Ceram. Soc. 82 (1999) 2155

[13] N. Cormack, in: G. Kordas, P. Chrysocopoulou (Eds.), Structure of Glass, Symposium, Harokopi University, Athens, 2002, p. 90.

[14] J.O. Isard, J. Non-Cryst. Solids 1 (1969) 235.

[15] Malcolm D. Ingram, The Mixed Alkali Effect in Glass: A puzzle solved? Department of Chemistry, University of Aberdeen, Aberdeen, AB24 3UE, UK.

[16] D.E. Day, J. Non-Cryst. Solids 21 (1976) 343.

[17] R.J. Kirkpatrick, R.K. Brow, Solid State Nucl. Magn. Reson. 5 (1995) 9.

[18] Malcom H. Levitt, Spin Dynamics Basics of Nuclear Magnetic Resonance, University of Stockholm, Sweden and University of Southampton, UK, John Wiley \& Sons, Ltd.

[19] J.P. Amoureux, C. Fernandez, S. Steuernagel, J. Magn. Reson. A123 (1996) 116.

[20] D. Massiot, J. Magn. Reson. A122 (1996) 240.

[21] H. Maekawa, T. Maekawa, K. Kawamura, T. Yokokawa, J. NonCryst. Solids 127 (1991) 53

[22] P. Zhang, C. Dunlap, P. Florian, P.J. Grandinetti, I. Farnan, J.F. Stebbins, J. Non-Cryst. Solids 204 (1996) 294.

[23] H. Yamashita, H. Yoshino, K. Nagata, H. Inoue, T. Nakajin, T. Maekawa, J. Non-Cryst. Solids 270 (2000) 48.

[24] H. Yamashita, K. Nagata, H. Yoshino, K. Ono, T. Maekawa, J. Non-Cryst. Solids 248 (1999) 115.

[25] R.K. Brow, R.J. Kirkpatrick, G.L. Turner, J. Non-Cryst. Solids 116 (1990) 39.

[26] J.A. Duffy, M.D. Ingram, J. Non-Cryst. Solids 21 (1976) 373.

[27] H. Yamashita, H. Yoshino, K. Nagata, I. Yamaguchi, M. Ookawa, T. Maekawa, J. Ceram. Soc. Jpn. 106 (1998) 539.

[28] M.W.G. Lockyer, D. Holland, R. Duprec, J. Non-Cryst. Solids 188 (1995) 207.

[29] J.F. Stebbins, J. Solid State Ionics 112 (1998) 137.

[30] Y. Tokuda, M. Takahashi, T. Yoko, Na environment in sodium silicate glasses by ${ }^{23} \mathrm{Na}$ MQ-MAS NMR spectroscopy and ab initio MO calculations, 2004. 